\title{
Safety of Oriental Medical Therapy: Drug Fever of Herbal Medicine and Procedure-related Fever
}

\author{
Soo-youn Moon, Kyoung Ree Lim, Jun Seong Son \\ Division of Infectious Diseases, Dept. of Internal Medicine, Kyung Hee University Hospital at Gangdong
}

\section{Safety of Oriental Medical Therapy: Drug Fever of Herbal Medicine and Procedure-related Fever}

\author{
Soo-youn Moon, Kyoung Ree Lim, Jun Seong Son \\ Division of Infectious Diseases, Dept. of Internal Medicine, Kyung Hee University Hospital at Gangdong
}

\begin{abstract}
Objectives: Drug fever and procedure-related fever are the causes of nosocomial fever. Oriental medicine has been practiced in Asia and is now being practiced as an alternative medicine in western countries. No data are available on the incidence of drug fever and procedure-related fever in oriental medical hospitals (OMHs). The aim of this study was to identify the incidence of drug fever related to oriental herbal medicine and oriental medical procedure-related fever.

Methods: This was a retrospective study at one OMH of a university medical institute in Seoul, Korea, conducted from June 2006 to June 2013.

Results: Overall, 95 episodes of drug fever occurred among 10880 patients treated with herbal medicine (0.89\%). Peak body temperature was $38.37 \pm 0.58{ }^{\circ} \mathrm{C}$, and the fever lasted for 1.0 day (range 1.0-17.0 days). Eosinophilia was found in 15 patients (15.79\%) and 8 patients developed toxic hepatitis (8.42\%). Five patients had a drug-related skin rash (5.26\%). The most common ingredients of the herbal medicines associated with drug fever were licorice, Angelica gigas root, and white Atractylodes rhizome. In total, 16 episodes of procedure-related fever (0.20\%) occurred in 8125 patients treated with oriental medical procedures. The peak body temperature was $38.26 \pm 0.51{ }^{\circ} \mathrm{C}$, and the fever lasted for 1.0 day (range 1.0-3.0 days). Among various oriental medical procedures, moxibustion was the most common procedure related to fever, followed by acupuncture.

Conclusions: The incidence of drug fever and procedure-related fever in oriental medicine is not high compared with the incidence in western medicine.
\end{abstract}

Key words: fever, drug fever, procedure-related fever, oriental medical therapy

\section{Introduction}

Fever is a common clinical event in hospitalized

· 투고일: 2021.11.19, 심사일: 2021.12.27, 게재확정일: 2021.12.27

- Corresponding author: Jun Seong Son Division of Infectious Diseases, Department of Internal Medicine, Kyung Hee University Hospital at Gangdong 892, Dongnam-ro, Gangdong-gu, Seoul, Korea TEL: 82-2-440-6129 FAX: 82-2-440-7073 E-mail: isonjs@ naver.com patients 1 . Although fever is frequently suspected and proven to be related to infections, diverse etiologies may account for fever in hospitalized patients ${ }^{1}$. Drug fever and procedure-related fever are among the causes of nosocomial fever.

Until now, there has been no data on the incidence of drug fever related to oriental herb medicine and oriental medical procedures. As far as we know, this is the first study on the 
epidemiology of drug fever and procedure-related fever from oriental medicine.

The medical centers in this study were composed of a medical hospital, an oriental medical hospital (OMH) and a dental hospital. Many patients were hospitalized for traditional medical treatment and some patients developed a fever. When patients in the oriental medical hospital developed a fever, many of them were consulted to the medical hospital for evaluation and treatment of the fever. So, we designed this study to identify the incidence of drug fever related to oriental herbal medicine and oriental medical procedure-related fever.

\section{Material and Methods}

This retrospective study was performed at one university medical institutes in Seoul, Korea. The medical institute consisted of 1 medical hospital, 1 $\mathrm{OMH}$ and 1 dental hospital. Patients hospitalized in OMHs from June 2006 to June 2013 were reviewed retrospectively. Patients of 18 years or older with fever were screened. Adult patients with an axillary temperature of $\geq 37.8{ }^{\circ} \mathrm{C}$ after 48 hours of hospitalization were enrolled. Patients were also considered if they were transferred from another $\mathrm{OMH}$ where they were admitted for more than 48 hours and then a fever started within 48 hours of hospitalization at our $\mathrm{OMH}$.

The study was approved and the informed consent was waived by Institutional Review Board of Kyung Hee University Hospital at Gangdong (IRB No.: KHNMC 2016-03-008).

Drug fever was defined by diagnostic criteria adapted from those described by Young et al . with some modifications: 1) an oral or rectal body temperature above $38.0{ }^{\circ} \mathrm{C}$ or axillary body temperature above $37.8{ }^{\circ} \mathrm{C}, 2$ ) the absence of other causes of fever as determined by physical examination and appropriate biological and microbiological tests (i.e., the absence of any infection), 3) the absence of any underlying condition causing the fever, 4) the coincidence of fever onset with drug administration, 5) disappearance of the fever within 72 hours following drug discontinuation without any other intervention, 6) no recurrence of the fever within at least 72 hours after normalization of temperature and 7) fever accompanied by drug rash when the fever was gone after discontinuation of the offending drug.

Fever was considered procedure-related if there was a transient body temperature elevation during a 48-hour period following a procedure and no evidence of infection elsewhere.

Among oriental medical procedures, acupuncture, direct moxibustion and wet cupping are defined as invasive oriental procedure as they can or highly likely to cause breakage of skin barrier.

When patient's peak body temperature is below $37.3{ }^{\circ} \mathrm{C}$ by axillary temperature for more than 2 days, we considered as defervescence.

McCabe classification was used to evaluate the severity of the underlying illnesses ${ }^{3}$.

Demographic characteristics, clinical features, laboratory data and treatment history were collected by review of medical records. Treatment history included the ingredients of the oriental herbal medicines, types of oriental medical procedures and the time relation to the fever.

SPSS for Windows version 11.0 (SPSS Inc., Chicago, IL, USA) was used for statistical analysis. Student's t-test and chi-square test were used for univariate analysis and logistic regression test was 
used for multivariate analysis. A $p$ value $<0.05$ was considered significant.

\section{Results}

A total of 11207 adult patients were hospitalized to the oriental medical hospital during the study period. Among these patients, 10880 patients (97.08\%) were treated with herbal medicine and 8125 patients (72.49\%) received oriental procedures. Of the 8125 patients received oriental procedures, 8040 patients (98.95\%) received acupuncture, 4267 patients (52.52\%) received cupping therapy and 6585 patients (81.05\%) received moxibustion. Some patients received 2 or more procedures simultaneously. Among those 11207 patients, 560 cases of nosocomial febrile events were identified $(5.00 \%)$.

There were 95 patients with drug fever related to herbal medicine, accounting for $0.89 \%$ of 10880 patients treated with herbal medicine. The mean age of the patients that experienced drug fever was $57.4 \pm 14.1$ years, and 43 patients were male (45.26\%) (Table 1). A total of 49 patients had an underlying malignancy (51.58\%) and 35 patients had underlying cerebrovascular events (cerebral infarction or intracranial hemorrhages) (36.84\%). During the febrile events, peak body temperature was $38.4 \pm 0.58{ }^{\circ} \mathrm{C}$, and the median duration of the fever was 1.0 day (range 1.0-17.0 days). Eosinophilia was found in 15 patients (15.79\%) and 8 patients developed toxic hepatitis $(8.42 \%)$. Five patients had drug-related skin rash (5.26\%). Some patients took more than 1 herbal medicine. The most common ingredients prescribed to the patients that experienced drug fever were: licorice (59 patients, $62.10 \%$ ), Angelica gigas root (46 patients, $48.42 \%$ ), white Atractylodes rhizome (46 patients, 48.42\%), jujube (43 patients, 45.26\%), Poria (43 patients, $45.26 \%$ ), ginseng (43 patients, $45.26 \%$ ), Scutellaria root (43 patients, 45.26\%), Rhois vernicifluae cortex (41 patients, $43.15 \%)$, Peony root (40 patients, $42.11 \%$ ) and Bupleurum root (40 patients, 42.11\%) (Table 2).

Table 1. Characteristics of Patients with Drug Fever Related to Herbal Medicine $(n=95)$

\begin{tabular}{lc} 
& \multicolumn{1}{c}{ No. of } \\
patients $(\%)$
\end{tabular}

DM : diabetes mellitus, HTN : hypertension, CVA : cerevrovascular attack

Table 2. Common Herbal Ingredients Related to Drug Fever

\begin{tabular}{cc}
\hline Herb ingredients & $\begin{array}{c}\text { No. of } \\
\text { patients }(\%)\end{array}$ \\
\hline Licorice & $59(62.10)$ \\
Angelica gigas root & $46(48.42)$ \\
White atractylodes rhizome & $46(48.42)$ \\
Jujube & $43(45.26)$ \\
Poria & $43(45.26)$ \\
Ginseng & $43(45.26)$ \\
Scutellaria root & $43(45.26)$ \\
Rhois vernicifluae cortex & $41(43.15)$ \\
Peony root & $40(42.11)$ \\
Bupleurum root & $40(42.11)$ \\
\hline
\end{tabular}


Sixteen patients experienced fever related to invasive oriental procedures, accounting for $0.20 \%$ of the 8125 patients treated with invasive oriental procedures. The mean age of those afflicted was $59.7 \pm 15.58$ years, and 10 patients were male $(62.50 \%)$ (Table 3). There were 8 patients with underlying cerebrovascular events $(50.00 \%)$ and 6 patients with underlying malignancy (37.50\%). Peak body temperature was $38.3 \pm 0.51{ }^{\circ} \mathrm{C}$, and the median duration of the fever was 1.0 day (range 1.0-3.0 days). Among the oriental procedures, moxibustion was the most common cause of procedure-related fever $(7 / 6585$ patients, $0.11 \%)$, followed by acupuncture $(8 / 8040$ patients, $0.10 \%)$ and cupping therapy (1/4267 patient, $0.02 \%$ ) (Table 4 ). Of the 16 patients with procedure-related fever, 2 patients developed infectious complications. One patient had septic arthritis of the knee joint after acupuncture and the other developed cellulitis of the arm after moxibustion.

Table 3. Characteristics of Patients with Fever Related to Invasive Oriental Procedures $(n=16)$

\begin{tabular}{|c|c|}
\hline & $\begin{array}{c}\text { No. of } \\
\text { patients }(\%)\end{array}$ \\
\hline \multicolumn{2}{|c|}{ Demographics and baseline characteristics } \\
\hline Age (years) & $59.69 \pm 15.58$ \\
\hline Male & $10(62.50)$ \\
\hline DM & $5(31.25)$ \\
\hline HTN & $7(43.75)$ \\
\hline CVA & $8(50.00)$ \\
\hline Malignancy & $6(37.50)$ \\
\hline Herbal medicine & $16(100.00)$ \\
\hline Invasive oriental procedures & $16(100.00)$ \\
\hline \multicolumn{2}{|c|}{ Procedure-related fever associated manifestation } \\
\hline Peak body temperature $\left({ }^{\circ} \mathrm{C}\right)$ & $38.26 \pm 0.51$ \\
\hline Duration of fever (days) & $1.0(1.0-3.0)$ \\
\hline Infectious complication* & $2(12.50)$ \\
\hline \multicolumn{2}{|c|}{$\begin{array}{l}\text { DM : diabetes mellitus, HTN : hypertension, CVA : } \\
\text { cerevrovascular attack } \\
\text { * Infectious complications : } 1 \text { cellulitis after moxibustion } \\
1 \text { septic arthritis after acupuncture }\end{array}$} \\
\hline
\end{tabular}

Table 4. Incidence of Procedure-related Fever Depending on the Oriental Medical Procedures

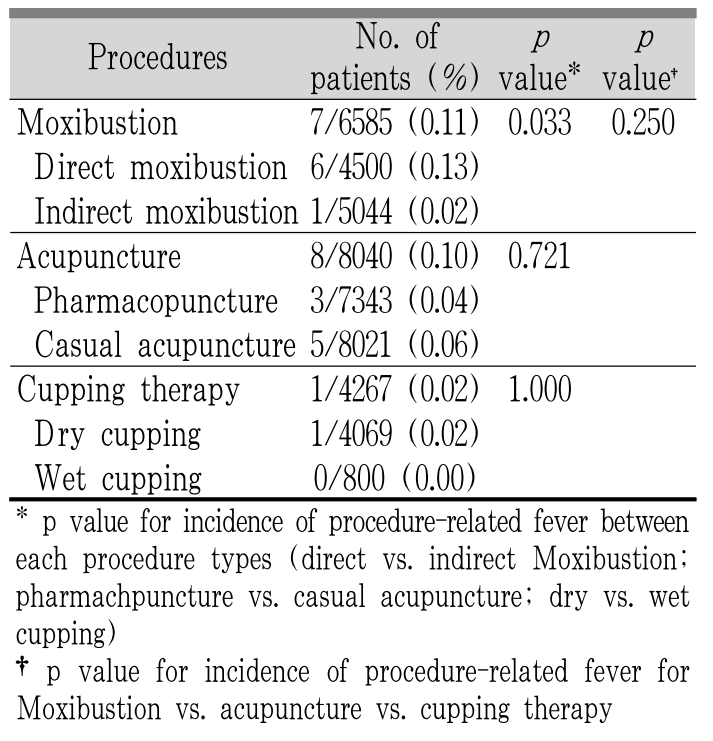

Among patients treated with moxibustion, the incidence of fever was higher in patients treated with direct moxibustion $(6 / 4500,0.13 \%)$ than in those treated with indirect moxibustion (1/5044, 0.02\%) $(p=0.033)$. Among patients treated with acupuncture, the incidence of fever depending on the type of acupuncture was not different statistically; 5 patients among 7343 patients with pharmacopuncture $(0.07 \%)$ and 3 patients among 8021 patients with conventional acupuncture $(0.04 \%)$ experienced a fever $(p=0.560)$. There was no statistically significant difference for the incidence of fever among moxibustion, acupuncture and cupping therapy $(p=0.250)$.

\section{Iv. Discussion}

Until now, the safety and adverse events of treatment modality of oriental medicine had not 
been systematically addressed. Indeed, there have not been any studies on the adverse events of herbal medicine such as fever, and adverse events related to oriental procedures such as fever and infections. As far as we know, this is the first study on the adverse events of oriental herbal medicine and oriental procedures.

Oriental traditional medicine uses acupuncture, moxibustion, cupping therapy, herbal medicines and manual therapies ${ }^{4}$.

Drug fever occurred in 95 patients accounting for $0.87 \%$ of 10880 patients treated with herbal medicine. According to a previous study, western medicine causes drug fever in 3-5\% of hospitalized patients in the US, which is higher than our results. In a study by Oisumi et al., parenteral antibiotic therapy caused drug fever in 13.1\% of 390 patients with pulmonary infections. Among the various kinds of medicines, antimicrobial agents are responsible for the largest number of episodes of drug fever?. There are some studies on the incidence of drug fever; these studies show rates of $5 \%$ in 19 patients with ceftriaxone treatment ${ }^{8}$, $45 \%$ in 107 patients treated with streptokinases ${ }^{9}$, and $3 \%$ of 824 patients treated with rifampin ${ }^{10}$. The incidence of drug fever caused by herbal medicine in our study is lower than those all of those western medicines. However, as oriental herb medicine usually contains more than one ingredient, it is hard to identify the exact ingredient(s) that cause drug fever. We only could identify which herb ingredients were prescribed frequently and can only presume that at least one of those ingredients was implicated in drug fever.

Incidence of procedure-related fever might depend on the severity of invasive procedures. There are some studies showing transient bacteremia or fever after general western medical procedures. In a study by Leshem-Rubinow et al., 22 episodes of fever were recorded following transfemoral transcatheter aortic valve implantation among 140 patients $(15.7 \%)^{11}$. In some studies on bacteremia after an endoscopic procedure, the incidence of transient bacteremia was $4.3-31.9 \% \%^{12-14}$. In another study, the estimated significant bacteremia rate after a CT colonography is $0-3.7 \%$. In a study by Sharif-Kashani et al., after a flexible fiberoptic bronchoscopy, transient bacteremia occurred in 1 patient (1.1\%) and fever in 9 patients (10.5\%) in the first 24 hours $^{16}$.

In our study, the incidence of oriental procedurerelated fever was not high, compared to that of various western medical procedures. This was expected for the following reasons. Fever associated with oriental medical procedures is often associated with transient bacteremia. However, most oriental medical procedures do not cause injuries severe enough to cause bacteremia. Among varieties of acupuncture, fever was associated with pharmacopuncture more commonly than casual acupuncture. Pharmacopuncture is a new acupuncture therapy in which purified herbal medicine or pharmacological medication is injected into acupoints ${ }^{17}$. Pharmacopuncture may trigger more complications than casual acupuncture because complications can be related to the acupuncture process or the herbal medicine ${ }^{18}$. Moxibustion or cupping therapy also can injure the cutaneous structures, but these procedures seldom injure the subcutaneous adipose tissue or deeper structures. Moxibustion can be direct or indirect, depending on the presence of a barrier such as the aconite cake or ginger partition. Direct moxibustion can cause burn and thermal injury to the cutaneous structures more often as there is no 
barrier such as the aconite cake or ginger partition. Cupping therapy can be classified as dry or wet depending on the presence of bleeding caused by cutaneous injuries such as needling and cuttings; dry cupping does not involve cutaneous injuries, while wet cupping accompanies cutting or needle injuries to the skin prior to cupping. As a result, wet cupping is more invasive and fever and transient bacteremia are more likely. In this study, direct moxibustion was more strongly associated with procedure-related fever than indirect moxibustion. However, there was no statistically significant difference on fever incidence between pharmacopuncture and casual acupuncture. This might be because only a small number of patients who were treated with acupuncture were afflicted with procedurerelated fever.

There are some limitations in this study. First, it was a retrospective study in OHM. Bacteria culture or imaging studies were not performed in every patient with nosocomial fever, so some patients with a hidden infection may not have been identified and classified as having drug fever or procedure-related fever. Second, this study was performed at one university teaching hospital with an oriental medical hospital, where there is a strict protocol for infection control. Usually, concept of sterilization, disinfection and adherence to infection control protocols may not be so strict in oriental medicine as in western medical hospitals. But, in our hospital, adherence to protocols for infection control was relatively high compared to other OMHs, therefore the infection rate might be lower. Lastly, there may have been some selection bias, as we screened patients with fever. There may have been some patients with other adverse events such as infection or toxic hepatitis without fever.
These patients were not screened and enrolled in this study.

In conclusion, the incidence of drug fever related to oriental herb medicine was not high, compared with most western medicine. Licorice (59 patients, 62.1\%). Angelica gigas root (46 patients, 48.4\%), white Atractylodes rhizome (46 patients, 48.4\%), jujube (43 patients, 45.3\%), Poria (43 patients, $45.3 \%$ ) and ginseng (43 patients, $45.3 \%$ ) were the most common herbal ingredients associated with fever. The incidence of fever related to oriental procedures was also relatively low, but some procedures may be as invasive as western procedures, which can be dangerous. Further study would be helpful to identify the incidence of fever and other adverse events related to oriental medical therapy.

Key message

1. The incidence of drug fever related to oriental herb medicine was not higher than that of most western medicine.

2. The incidence of fever related to oriental procedures was also relatively low, but some procedures may be as invasive as western procedures, which can be dangerous.

\section{Acknowledgements}

We would like to thank e-World Editing (eworldediting.com) for English language editing.

Financial support: This research did not receive any specific grant from funding agencies in the public, commercial, or not-for-profit sectors.

Data Availability: All data are included within the manuscript.

Conflicts of Interest: All authors declare no conflicts of interest.

Author contribution: S-y Moon - data curation 
\& formal analysis, conceptualization and writing -original draft; KR Lim - visualization; JS Son writing - reviewing and editing, conceptualization and supervision

\section{References}

1. Arbo MJ, Fine MJ, Hanusa BH, Sefcik T, Kapoor WN. Fever of nosocomial origin: etiology, risk factors, and outcomes. The American journal of medicine 1993:95(5) :505-12.

2. Young EJ, Fainstein V, Musher DM. Drug-induced fever: cases seen in the evaluation of unexplained fever in a general hospital population. Reviews of infectious diseases 1982;4(1):69-77.

3. McCabe WR, Jackson G. Gram-Negative Bacteremia:

I. Etiology and Ecology. Archives of internal medicine 1962;110(6) :847-55.

4. Cheung F. TCM: Made in China. Nature 2011; 480(7378) :S82-3.

5. Patel RA, Gallagher JC. Drug fever. Pharmacotherapy 2010:30(1):57-69.

6. Oizumi K, Onuma K, Watanabe A, Motomiya M. Clinical study of drug fever induced by parenteral administration of antibiotics. The Tohoku journal of experimental medicine 1989;159(1):45-56.

7. Mackowiak PA. Drug fever: mechanisms, maxims and misconceptions. Am J Med Sci 1987;294(4): 275-86.

8. Bradsher RW. Ceftriaxone (Ro 13-9904) therapy of serious infection. Antimicrob Agents Chemother 1982;22(1):36-42.

9. Ness PM, Simon TL, Cole C, Walston A. A pilot study of streptokinase therapy in acute myocardial infarction: observations on complications and relation to trial design. Am Heart $J$ 1974;88(6): 705-12.
10. Dutt AK, Moers D, Stead WW. Undesirable side effects of isoniazid and rifampin in largely twice-weekly short-course chemotherapy for tuberculosis. Am Rev Respir Dis 1983;128(3): 419-24.

11. Leshem-Rubinow E, Amit S, Steinvil A, Ben-Assa E, Abramowitz Y, Keren G, et al. Frequency, pattern, and cause of fever following transfemoral transcatheter aortic valve implantation. The American journal of cardiology 2014;113(6): 1001-5.

12. Bonilha DQ, Correia LM, Monaghan M, Lenz L, Santos M, Libera ED. Prospective study of bacteremia rate after elective band ligation and sclerotherapy with cyanoacrylate for esophageal varices in patients with advanced liver disease. Arq Gastroenterol 2011;48(4):248-51.

13. Chen WC, Hou MC, Lin HC, Yu KW, Lee FY, Chang FY, et al. Bacteremia after endoscopic injection of N-butyl-2-cyanoacrylate for gastric variceal bleeding. Gastrointest Endosc 2001;54(2): 214-8.

14. Itaba S, Iboshi Y, Nakamura K, Ogino H, Sumida Y, Aso A, et al. Low-frequency of bacteremia after endoscopic submucosal dissection of the stomach. Dig Endosc 2011;23(1):69-72. doi: 10.1111/j.1443-1661.2010.01066.x.

15. Ridge CA, Carter MR, Browne LP, Ryan R, Hegarty C, Schaffer K, et al. CT colonography and transient bacteraemia: implications for antibiotic prophylaxis. Eur Radiol 2011;21(2): 360-5. doi: 310.1007/s00330-00010-01933-00331. Epub 02010 Aug 00315.

16. Sharif-Kashani B, Shahabi P, Behzadnia N, Mohammad-Taheri Z, Mansouri D, Masjedi $\mathrm{MR}$, et al. Incidence of fever and bacteriemia following flexible fiberoptic bronchoscopy: a 
prospective study. Acta Med Iran 2010;48(6):

$385-8$.

17. Cheon S, Zhang X, Lee IS, Cho SH, Chae Y, Lee H. Pharmacopuncture for cancer care: a systematic review. Evidence-based complementary and alternative medicine : eCAM 2014;2014:
804746. : 10.1155/2014/804746. Epub 802014 May 804712.

18. Koo EH, Choi SS, Chung DH, Lee IO, Kim NS, Lim SH. Multiple Psoas Abscess Formation after Pharmacopuncture: A Case Report. Korean J Pain 2010;23(4):270-3.

\title{
한방치료의 안전성 : 한약에 의한 약열과 시술관련 발열
}

\author{
문수연, 임경리, 손준성 \\ 강동경희대병원 감염내과
}

\section{ABSTRACT}

목적: 약열과 시술관련 발열(시술열)은 원내 발열의 원인이다. 한방은 여러 라에서 시행되나. 이에 의한 약열과 시술열의 빈도에 대한 자료는 없다. 본 연구의 목적은 한방치료에 의한 약열과 시술열의 빈도를 확인하는 것이다.

방법: 2006년부터 8년간 서울의 한 대학 부속 한방병원에서 후향적으로 시행했다.

결과: 한약을 복용한 10800 명의 환자 중 95 건의 약열이 발생하였다 $(0.89 \%)$. 환자들의 체온은 $38.37 \pm 0.58{ }^{\circ} \mathrm{C}$ 이었고, 발열은 평균 1 일간 지속되었다. 호산구증, 독성간염, 피부발진이 각각 $15.79 \%, 8.42 \%, 5.26 \%$ 에서 발생하였다. 약열과 관련된 흔한 한약 재는 감초, 당귀, 백출이었다.

한방 시술을 받은 8125 명의 환자 중 16 건의 시술열이 발생하였다 $(0.20 \%)$. 환자들의 체온은 $38.26 \pm 0.51{ }^{\circ} \mathrm{C}$ 이었고, 발열은 평 균 1일간 지속되었다. 뜸이 가장 흔한 원인으로, 침이 두 번째였다.

결론: 한방치료에 의한 약열 및 시술열의 빈도는 서양의학보다 높지 않다.

중심어: 발열, 약열, 시술열, 한방치료 